\title{
TEKSTUALISME DAN KONTEKSTUALISME PENAFSIRAN KONTEMPORER TERHADAP SURAH AL-MAIDAH AYAT 38
}

\author{
Umi Hidayati \\ Institut Agama Islam Cirebon \\ umyhidayati@gmail.com \\ Athoillah Islamy \\ Institut Agama Islam Negeri Pekalongan \\ athoillahislamy@yahoo.co.id
}

\begin{abstract}
ABSTRAK
Tidak hanya dalam penafsiran ulama klasik, diskursus penafsiran ulama kontemporer juga beragam bahkan sering bertentangan meski berpijak pada landasan teks ayat al-Qur'an yang sama. Penelitian ini bermaksud untuk mengidentifikasi corak penafsiran ulama kontemporer tentang sanksi hukum potong tangan dalam al-Maidah ayat 38. Dua tokoh yang dikaji, yakni Ibnu 'Asyur dan Muhammad Syahrur. Objek data utama penelitian ini, yakni buku (kitab) berjudul al-Tahrîr wa al-Tanwîr karya Muhammad Tahir Ibn 'Asyur, dan al-Kitâb wa al-Qur'ân Qirâ'ah Mu'âsirah karya Muhammad Syahrur. Pendekatan penelitian yang digunakan yakni pendekatan normatif filosofis. Teori analisis yang digunakan yakni tipologi tekstualisme dan kontekstualisme penafsiran yang dicetuskan oleh Abdullah Saeed. Sementara itu, sifat pendekatan penelitian yakni deskriptif-analitik. Hasil penelitian menyimpulkan penafsiran Ibnu 'Asyur terkait al-Ma'idah ayat 38 dapat dikategorikan sebagai penafsiran tekstual. Hal ini dapat dilihat dari penafsirannya atas makna harfiyah dari ayat tersebut. Selain itu, Ibnu 'Asyur juga cenderung memandang hukuman potong tangan bagi pencuri agar jera sekaligus sebagai upaya prefentif. Berbeda dengan Ibnu 'Asyur, penafsiran Muhammad Syahrur pada kasus hukum potong tangan bagi pencuri termasuk penafsiran kontekstual. Hal ini dapat dilihat ketika ia memahami ayat potong tangan bagi pencuri, ia memberikan pemaknaan yang memberi ruang ijtihad bagi suatu daerah dan kondisi tertentu untuk menegakkan hukuman yang memberi efek jera, dengan ketentuan tidak boleh melampaui hukuman potong tangan sebagai batas maksimal.
\end{abstract}

Kata Kunci: Tekstualisme, Kontekstualisme, Penafsiran, Muhammad Tahir Ibn 'Asyur, Muhammad Syahrur 


\begin{abstract}
Not only in the interpretation of classical scholars, the discourses on the interpretation of contemporary scholars are also diverse and often contradictory even though they are based on the same textual basis of the Qur'anic verse. This study intends to identify trends in the interpretation of contemporary scholars regarding the legal sanctions for cutting hands in al-Maidah verse 38. Two figures are studied, namely Ibn 'Asyur and Muhammad Syahrur. The main data objects of this research, namely the book (kitab) entitled al-Tahrîr wa al-Tanwîr by Muhammad Tahir Ibn 'Asyur and al-Kitâb wa al-Qur'ân Qirâ'ah Mu'âsirah by Muhammad Syahrur, and. The research approach used is a philosophical normative approach. The analytical theory used is the typology of textualism and contextualism of interpretation which was coined by Abdullah Saeed. Meanwhile, the nature of the research approach is descriptive-analytic. The results of the study conclude that the interpretation of Ibn 'Asyur regarding al-Ma'idah verse 38 can be categorized as a textual interpretation. This can be seen from his interpretation of the literal meaning of the verse. In addition, Ibn 'Asyur also tends to view the punishment of cutting off hands for thieves to be a deterrent as well as a preventive measure. In contrast to Ibn 'Asyur, Muhammad Syahrur's interpretation of the legal case of cutting off hands for thieves includes contextual interpretation. This can be seen when he understands the verse of cutting off hands for thieves, he gives a meaning that gives space for ijtihad for an area and conditions to enforce punishments that have a deterrent effect, provided that it must not exceed the punishment of cutting off handsas the maximum limit.
\end{abstract}

Keywords: Textualism, Contextualism, Interpretation, Muhammad Tahir Ibn 'Asyur, Muhammad Syahrur

\title{
A. PENDAHULUAN
}

Interpretasi (penafsiran) atas sebuah kasus hukum dalam nas (ayat) al-Qur'an sering menimbulkan ragam penafsiran. Hal demikianlah yang kemudian sering memicu ragam perbedaan pendapat hukum Islam (fiqh) meski berpijak pada teks ayat yang sama. Sebagai contoh terkait sanksi bagi pelaku kasus pencurian misalnya, dalam perspektif hukum pidana Islam (fiqh al-jinayah), pencurian dipandangan sebagai salah satu jenis tindak pidana (jarimah) yang sanksi hukumannya berupa potong tangan. Penjelasan demikian sebagaimana keterangan normatif dalam surat al-Maidah ayat 38 yang menyatakan bahwa seorang laki-laki yang mencuri dan seorang perempuan yang melakukan pencurian, maka potonglah tangan keduanya sebagai bentuk hukuman dan sebagai siksaan dari Allah. Namun penafsiran hukum dalam ayat tersebut melahirkan ragam penafsiran (Ulummudin 2019: 152).

Terjadinya ragam penafsiran hukum atas al-Maidah ayat 38 merupakan hal yang niscaya, mengingat dalam ayat tersebut tidak dijelaskan detail konsep penerapan sanksi potong tangan bagi pelaku pencurian, seperti bagian tangan 
mana yang dipotong, objek apa yang dicuri, dan kadar curian sampai berapa yang menyebabkan sanksi hukum potong tangan tersebut diterapkan (Rahmi 2018:54). Oleh sebab itu, menjadi niscaya jika terjadi ragam penafsiran di kalangan mufassir sekaligus mujtahid dalam memahami konsep sanksi hukum potong tangan yang termaktub dalam al-Maidah ayat 38 .

Tidak berhenti di kalangan ulama klasik, ragam penafsiran juga terjadi pada penafsiran ulama kontemporer. Muhammad Tahir Ibn 'Asyur misalnya, ia cenderung menerima pelaksanaan hukum potong tangan bagi pelaku pencurian. Menurutnya, penerapan sanksi tersebut mengandung aspek kemaslahatan (mashlahat) bagi keberlangsungan hidup manusia (Asyur 1984: 190-92). Berbeda dengan Ibn 'Asyur, Muhammad Syahrur menuturkan sanksi hukum potong tangan dalam al-Maidah ayat 38 merupakan bentuk hukuman batas maksimal. Syahrur menambahkan para mujtahid penting mempertimbangkan sebuah sanksi kasus pencurian, apakah masuk kategori batas hukuman maksimal atau minimal (Syahrur 1990:455).

Distingsi penafsiran hukum dari kedua tokoh kontemporer (Ibn 'Asyur dan Syahrur) sebagaimana di atas menarik untuk dicermati lebih lanjut. Mengingat keduanya dapat dikatakan sebagai tokoh pakar hukum Islam kontemporer yang dikenal banyak memberikan kontribusi ide progresif dalam pemikiran hukum Islam. Namun fakta menunjukan, bahwa keduanya memiliki perbedaan penafsiran hukum atas sanksi hukum potong tangan bagi pelaku pencurian yang mengacu pada landasan teks normatif ayat yang sama. Berpijak pada kegelisahan akademik inilah, penelitian ini bermaksud untuk mengidentifikasi corak penafsiran hukum antara Ibn 'Asyur dan Muhammad Syahrur terkait al-Maidah ayat 38 .

Penulis menyadari telah ada berbagai penelitian terdahulu yang memiliki relevansi dengan objek inti pembahasan penelitian ini. Diawali oleh Nursyamsudin (2016) dalam penelitian berjudul "Metodologi Hukum Muhammad Shahrur: Tafsir Hadd Pencurian Dalam Qs. Al-Mā'idah (5): 38." Pada penelitian tersebut dijelaskan bahwa Syahrur menuturkan sanksi hukuman potong tangan bagi pencuri dalam al-Maidah ayat 38 tidak otomatis dapat diterapkan, melainkan harus mempertimbangkan aspek kemaslahatan umat manusia. Syahrur menambahkan sanksi tersebut baru dapat diterapkan bagi kasus seorang seorang yang sudah berulang kali melakukan pencurian dan tanpa ada rasa penyesalan (Ridwan 2016:230). Secara global, kesimpulan penelitian Nursyamsudin ini memiliki titik relevansi yang cukup erat dengan objek penelitian ini, khususnya dalam aspek produk penafsiran Syahrur atas implementasi sanksi hukum potong tangan dalam al-Maidah ayat 38. Namun penelitian Nursyamsudin tidak menyinggung bagiamana corak penafsiran Syahrur tersebut sebagai pemikir hukum Islam kontemporer, dan juga tidak berupaya mengkomparasikan dengan corak penafsiran Ibn 'Asyur.

Berikutnya, penelitian Nailul Rahmi (2018) yang berjudul "Hukuman Potong Tangan Perspektif al-Qur'an dan Hadis." Penelitian Rahmi menyatakan terdapat ragam pendapat hukum tentang karakteristik jenis pencurian yang menyebabkan pelakunya dikenai sanksi hukum potong tangan sebagaimana yang termaktub dalam surat al-Maidah ayat 38 (Rahmi 2018:69). Penelitian Rahmi ini hanya mengkaji ragam pendapat fikih ulama atas konsep sanksi hukum potong tangan dalam al-Qur'an tidak fokus mengkaji perbandingan corak penafsiran Ibn 'Asyur dan Syahrur. 
Kemudian penelitian Firqah Annajiyah Mansyuroh (2019) dengan judul "Hukum Potong Tangan Bagi Koruptor (Kajian Ahkam Surah Al-Maidah Ayat 38)," Penelitian Firqah ini menjelaskan term koruptor tidak dapat dimasukan dalam kategori term pencuri sebagaimana dalam surah al-Maidah ayat 38. Oleh sebab itu, seorang koruptor tidak dapat dijatuhi hukuman berupa potong tangan, disebabkan kategori pelaku pencurian dalam al-Maidah ayat 38 merupakan seseorang yang mencuri harta dengan sembunyi-sembunyi dari tempat penyimpanannya melalui cara yang tidak dibenarkan oleh hukum, dan bukan karena syubhat. Sedangkan koruptor merupakan seseorang yang tidak dapat bersikap amanah, seperti melakukan penyuapan, penggelapan yang menimbulkan kerugian besar bagi negara (Mansyuroh 2019:56). Sebagaimana penelitian Rahmi, penelitian Firqah tersebut masih dapat dikatakan global dalam mengkaji pemikirann tokoh atas konsep sanksi hukum potong tangan dalam al-Ma'idah ayat 38 .

Berpijak dari berbagai penelitian terdahulu di atas, menunjukan sebuah lacuna (ruang kosong) penelitian kompratif atas corak penafsiran Muhammad Tahir Ibn'Asyur dan Muhammad Syahrur dalam memahami sanksi hukuman potong tangan pada surah al-Maidah ayat 38 . Hal inilah yang akan menjadi distingsi penelitian ini dari berbagai penelitian yang sudah ada. Penelitian ini penting dilakukan mengingat kedua tokoh tersebut merupakan pakar hukum Islam kontemporer yang dikenal memiliki ide pembaharuan hukum Islam yang kontekstual. Namun fakta menunjukan penafsiran hukum keduanya khususnya terkait sanksi hukum potong tangan dalam al-Maidah ayat 38 terjadi perbedaan. Sebagaimana penjelasan sebelumnya, bahwa Ibnu 'Asyur terkesan lebih memahami makna tekstual dari redaksi ayat tersebut. Sedangkan Syahrur lebih memahami dimensi konteks dari ayat tersebut melalui pendekatan teori hudud (batas) yang dicetuskannya.

Penelitian kualitatif ini berupa kajian pustaka (Moleong 2017:6).Objek data utama penelitian ini, yakni buku (kitab) berjudul al-Kitâb wa al-Qur'ân Qirâ'ah Mu'âsirah karya Muhammad Syahrur, dan al-Tahrîr wa al-Tanwîr karya Muhammad Tahir Ibn 'Asyur. Jenis pendekatan penelitian yakni pendekatan normatif filosofis. Teori analisis yang digunakan yakni tipologi tekstualisme dan kontekstualisme penafsiran yang dicetuskan oleh Abdullah Saeed. Pelbagai instrumen dalam tipologi penafsiran tersebut akan diaplikasikan sebagai teori analisis dalam mengidentifikasi corak penafsiran Ibn 'Asyur dan Muhammad Syahrur terkait penafsiran sanksi hukuman potong tangan dalam al-Ma'idah ayat 38 .

\section{B. DISKURSUS ONTOLOGIS PENAFSIRAN TEKSTUAL DAN KONTEKSTUAL}

Terdapat dua pendekatan penafsiran yang senantiasa menjadi isu menarik dalam studi tafsir al-Qur'an kontemporer, yakni pendekatan tekstual dan kontekstual. Adapun pendekatan tekstual merupakan pendekatan penafsiran al-Qur'an yang menjadikan teks ayat al-Qur'an sebagai objek inti penafsiran. Dalam langkah operasionalnya, pendekatan ini memiliki kecenderungan atas penekanan analisis pada aspek linguistik (kebahasaan) dalam memahami maksud kandungan teks al-Qur'an. Oleh karena itu, tidaklah 
berlebihan jika dikatakan pendekatan tekstual merupakan pemahaman yang rigid, dikotomis, atomoistik, dan historis. Karakter demikianlah yang kemudian seringkali menimbulkan problem produk penafsiran ketika dikorelasikan dengan kondisi zaman dan kebutuhan umat modern yang kompleks dan dinamis. Meski demikian, pendekatan ini sejatinya telah banyak diaplikasikan oleh para mufassir salaf dalam menafsirkan teks ayat al-Qur'an (Tazkiyah 2018:621-623).

Abdullah Saeed menuturkan bahwa pendekatan tekstual merupakan pendekatan penafsiran yang mengacu pada makna harfiah dari redaksi teks ayat al-Quran. Menurut Saeed, paradigma dalam pendekatan tekstual memiliki dasar keyakinan bahwa makna yang termuat dalam redaksi teks al-Qur'an bersifat universal, yakni dapat diimplementasikan melintasi ruang dan waktu tanpa harus mengacu pada latar belakang sosio-historis ketika teks al-Qur'an tersebut diturunkan (Kharomen 2018:190).

Lebih lanjut Saeed sebagaimana yang dikutip Izzah Tazkiyyah, mengklasifikasikan para mufassir yang menggunakan pendekatan tekstual kedalam dua tipologi mufassir tekstualis, yakni kelompok tekstualis lunak (soft textuliasm) dan kelompok tekstualis keras (hard textualis). Bagi kelompok tektualis lunak, mereka melandaskan makna literal (redaksional) sebagai basis makna dalam proses penasirannya, akan tetapi tidak ekslusif menutup diri dari upaya menghadirkan kemungkinan penafsiran lain dengan tetap mempertahankan makna berpijak riwayat. Dengan kata lain, kelompok ini masih memiliki kemungkinan memproduksi produk penafsiran secara flekibel. Sedangkan bagi kelompok tekstualis keras, mereka memahami makna literal teks ayat secara rigid tanpa disertai pertimbangan kompleksitas makna yang terkandung dalam teks ayat. Pada konteks dewasa ini, kelompok kedua sering diidentikkan dengan aliran salafisme kontemporer (Tazkiyah 2018:622).

Berbeda dengan pendekatan tekstualis, pendekatan kontekstual merupakan pendekatan yang tidak sekedar melihat keumuman teks ayat tetapi lebih dipengaruhi oleh latar belakang turunnya teks. Pada pendekatan ini, upaya penafsiran teks ayat harus dikaitkan dengan pertimbangan kondisi konteks peristiwa dan sosial budaya yang melitari turunya teks ayat tersebut. Secara sederhana dapat dikatakan bahwa penafsiran kontekstual merupakan paradigma, baik terkait cara, metode maupun pendekatan penafsiran yang tidak sekedar mengacu pada makna tekstual ayat, melainkan melibatkan pelbagai unsur terkait aspek sosio-historis dari munculnya teks ayat tersebut (Sama'un 2019:26-27).

Menurut Abdullah Saeed, terdapat lima hirarki nilai yang harus dipahami dalam kontekstualisasi penafsiran ayat-ayat hukum. Penjelasan lebih lanjut, sebagai berikut.

Pertama, nilai-nilai yang bersifat kewajiban (obligatory values). Saeed menyatakan tidak ada ruang untuk mengkontekstualisasikan pelbagai nilai pada level ini. Hal tersebut disebabkan nilai pesan hukum pada level ini bersifat kewajiban yang berlaku universal, tidak bergantung pada pada tempat dan waktu. Saeed menyatakan terdapat tiga kategori nilai yang masuk pada level ini, antara lain ayat keimanan (akidah), praktik ibadah, dan ketentuan hukum atas halal dan haram dalam kondisi normal, bukan darurat (Saeed 2005:130-132).

Kedua, nilai-nilai dasar kemanusiaan (fundamental values). Saeed menyatakan pelbagai nilai pada level ini berkaitan erat dengan nilai dasar 
dalam kehidupan manusia, seperti menjaga kemaslahatan jiwa, agama, akal, harta, dan keluarga. Dalam paradigma ushul fikih, pelbagai nilai dasar tersebut biasa disebut dengan istilah maqasid shariah al-khomsah (Saeed 2005:132134).

Ketiga, nilai nilai proteksional (protectional values). Saeed menuturkan nilai pada level ini merupakan bentuk proteksi terhadap nilai yang ada pada level sebelumnya, yakni nilai-nilai dasar kemanusiaan (fundamental values). Dengan kata lain, fungsi nilai proteksional dimaksudkan untuk memelihara keberlangsungan nilai fundamental. Sebagai contoh, untuk menjaga harta milik sebagai nilai fundamental, maka dalam al-Qur'an terdapat nilai proteksional yang berupa larangan mencuri.

Keempat, nilai-nilai implementasi (implementation values). Saeed menuturkan pelbagai nilai pada level ini merupakan langkah konkrit yang bersifat teknis dalam menjaga nilai-nilai fundamental. Ia mencontohkan pencegahan pencurian dalam al-Qur'an diaktualisasikan melalui sanksi hukum potong tangan. Sanksi hukum yang berupa potong tangan tersebut merupakan bentuk legal instrumen sebagai langkah prefentif agar tidak terjadi pelanggaran yang serupa. Menurut Saeed, sebagai bentuk legal instrument, sanksi hukum bagi orang yang mengambil hak milik orang lain tidak hanya dalam bentuk potong tangan, tetapi dapat dikontekstualisasikan dalam beragam bentuk yang efektif sesuai dengan kondisi yang ada (Saeed 2005:134-136).

Kelima, nilai-nilai intruksional (intructional values). Menurut Saeed, pelbagai nilai pesan hukum yang terkandung dalam ayat-ayat intruksional dapat berupa redaksi perintah maupun larangan. Pelbagai ayat dalam level nilai intruksional ini sangat erat dengan situasi dan kondisi yang ada pada saat-saat pewahyuan al-Qur'an, sehingga fungsi pesan hukumnya tidak otomatis berlaku universal. Contoh hukum intruksional dalam al-Qur'an, antara lain, ayat perintah poligami (al-Nisa' ayat 3), perintah laki-laki sebagai pemimpin prempuan (al-Nisa' ayat 34), perintah tidak menjadikan orang kafir sebagai pemimpin atau penolong (al-Nisa' ayat 89 ).

Pembedaan pendekatan tekstual dan kontekstual menurut Saeed didasarkan pada sejauh mana penafsir mengandalkan hanya pada aspek kebahasaan dalam menentukan makna teks dan memperhatikan konteks sosiohistoris al-Qur'ân dengan konteks saat ini. Lebih lanjut, Saeed juga memaparkan yang dimaksud tekstualis dan kontekstualis. Tekstualis menurutnya, yaitu penafsir yang perdebatannya hanya sebatas bunyi teks saja, dengan didukung pendekatan teks juga. Selain itu, tekstualis juga memahami bahwa al-Qur'ân berperan sebagai pembimbing manusia dan menjadikan bahwa teks yang ada bernilai universal dan harus diterapkan. Berbeda dengan kontekstualis, di mana menurut Saeed bahwa yang dimaksud kontekstualis adalah mereka yang lebih menekankan pada konteks sosio-historis dari sebuah teks, untuk kemudian dicari maknanya. Kaum kontekstualis mencari maksud dari teks secara jelas, dengan dilihat dari sisi konteks politik, sosial, sejarah, budaya, dan ekonomi pada waktu teks tersebut diturunkan, bahkan Saeed juga memasukkan kontekstualis sebagai mereka yang berpikir progresif dan liberal (Saeed 2005:3). Pendekatan tekstual dan kontesktual yang diklasifikasikan oleh Saeed ini akan digunakan sebagai teori analisis dalam mengidentifikasi mengidentifikasi corak penafsiran Muhammad Tahir Ibn 'Asyur dan 
Muhammad Syahrur terkait penafsiran sanksi hukuman potong tangan dalam al-Ma'idah ayat 38.

\section{HISTORISITAS SANKSI HUKUMAN POTONG TANGAN BAGI PENCURI}

Kajian tentang dunia Arab, terutama fase pra-kerasulan Nabi Muhammad telah banyak dilakukan para intelektual, baik dari belahan Timur maupun Barat (Karim 2003:7). Di antara peneliti tersebut adalah Khalil yang berhasil mendapatkan beberapa data yang menunjukkan bahwa Islam datang pada bangsa Arab yang sudah memiliki tradisi dan budaya, hal ini dapat diketahui dari adanya berbagai ritus yang ada, yaitu peribadatan, sosial, ritusritus hukuman, peperangan, dan politik. Kedatangan Islam pada waktu itu menjadi penghapus hukum yang ada, pembawa hukum baru, ataupun menerima tradisi yang sudah ada namun dengan didasari syarat-syarat. Demikian juga dengan hukum potong tangan bagi pencuri juga merupakan warisan dari tradisi yang ada pada waktu itu, lebih spesifik Khalil juga mengatakan bahwa hukum ini adalah warisan penganut tradisi haniffiyyah yang mereka tidak terkontaminasi oleh nafsu penyembahan berhala-berhala, juga tidak menganut agama Yahudi dan Nasrani, akan tetapi mengakui keesaan Allah. Kelompok ini berpandangan bahwa agama yang benar di sisi Allâh adalah hanîfiyyah, sebagai aktualisasi dari millah Ibrâhîm a.s (Karim 2003:2-16).

Dari pemaparan Khalil di atas dapat dipahami bahwa hukum potong tangan adalah tradisi yang diwarisi dari hanîfiyyah dan artinya tradisi tersebut sudah ada pra Islam dan Islam datang sebagai pemelihara tradisi tersebut. Namun jika dilihat secara eksplisit dalam ayat al-Qur'ân surat Yûsûf/12: 73-78 yang menjelaskan bahwa pada tradisi Nabi Yûsûf pencuri tidak dihukumi potong tangan melainkan dijadikan budak selama satu tahun karena syari'at Nabi Ya'kub adalah "Barang siapa mencuri maka hukumannya adalah dijadikan budak satu tahun”(R.I 2010:244).

Menurut Ibrâhim ketika memaparkan sejarah hukuman bagi pencuri pada masa pra Islam (al-Syatawî 1998:14-16) bahwa landasan yang dapat dijadikan penjelasan mengenai pelaksanaan hukuman bagi pencuri pertama kali hanya ada dua sumber, pertama dari al-Qur'ân yakni surat Yûsûf/12: 74-76, dan yang kedua sebuah riwayat dari 'Âisyah. Dari keduanya dapat dipahami bahwa ada syari'at sebelum Islam yakni pada masa Nabi Yûsûf yang tidak memberlakukan hukuman bagi pencuri jika diketahui bahwa pelaku pencurinya merupakan orang yang dimuliakan, seperti orang kaya dan keluarga raja, sedangkan jika pencuri dari orang biasa maka hukumannya adalah dijadikan budak. Selain itu juga ada riwayat lain yang menjelaskan bahwa syari'at pada era Nabi Ya'kub dan Nabi Yûsûf tentang hukum dijadikan budak dihapus oleh syari'at pada masa Nabi Mûsâ yakni berupa hukum potong tangan. Riwayat ini adalah hadis yang dikeluarkan oleh al-Nasâî. Selain penjelasan di atas, Ibrâhîm juga memaparkan pendapat Ibn Katsîr di dalam tafsirnya bahwa hukum potong tangan yang telah ada dalam Islam adalah tradisi yang sudah ada semenjak pra Islam (jâhiliyyah) adapun peran Islam dalam hukum ini adalah menerima dan menjadikan hukum syari'at, namun dengan disertai syarat-syarat dan ketentuan. Selain hukum ini yang diadopsi oleh Islam, ada beberapa tradisi 
lainnya yang juga dijadikan Islam sebagai hukum syari'at, seperti al-qasâmah, al-qarad, dan al-diyah(al-Dimasyqî 1998:97). Hal ini berbeda dengan al-Tabarî yang menjelaskan bahwa pada masa Nabi Yûsûf hukuman pencurian tidak dapat dilaksanakan jika pencuri sendiri dari keluarga kerajaan, selain jika pencuri bukan dari keluarga kerajaan, maka tampaknya hukuman tersebut dapat digantikan dengan orang lain, hal ini terlihat adanya dari penawaran saudara-saudara Yûsûf yang diajukan kepada raja agar hukuman Bunyamin dapat digantikan oleh saudaranya yang lain dikarenakan Bunyamin adalah putra yang sangat dikasihi oleh Nabi Ya'kub yang pada waktu itu sedang mengalami kebutaan (al-Tabarî 2001:279).

Dari penjelasasn-penjelasan yang telah penulis sajikan, maka dapat diambil beberapa kesimpulan mengenai sejarah hukuman bagi pencuri. Pertama,pada masa awal, yakni ketika pemerintahan Nabi Yûsûf pemberlakuan hukuman bagi seorang pencuri adalah dengan memenjarakannya atau dijadikan budak.Kedua,syari'at Nabi Ya'kub pada masa pemerintahan Nabi Yûsûf dihapus dengan syari'at Nabi Mûsâ, yaitu mengganti perbudakan dengan potong tangan.Ketiga,pemberlakuan hukum potong tangan terus berlangsung sampai pada masa sebelum pra Islam. Kemudian Islam mengadopsinya dengan menambahi syarat-syarat yang harus dipenuhi ketika akan dilakukan potong tangan bagi pencuri.

\section{DIASPORA INTELEKTUAL MUHAMMAD TAHIR IBNU ASYUR DAN MUHAMMAD SYAHRUR}

Muhammad Tahir Ibnu 'Asyur merupakan ulama kontemporer asal Tunisia. Ia memiliki nama lengkap Muhammad al-Thahir ibn Muhammad ibn Muhammad al-Thahir ibn Muhammad ibn Muhammad al- Syadzuliy ibn Abd al-Qadir ibn Muhammad ibn 'Asyur. Ibnu 'Asyur lahir di Mursi pada tahun 1296 H atau pada September tahun 1879 M (Arni 2011:81). Ibn 'Asyur dibesarkan dalam lingkungan keluarga yang sangat mencintai ilmu.Hal demikian terlihat, sejak masa kecilnya ia sudah belajar al-Qur'an, baik hafalan,tajwid, maupun qira'at-nya di lingkungannya.Setelah berhasil menghafal al-Qur'an, ia belajar di lembaga Zaitunah. Di mana penting diketahui bahwaZaitunah merupakan sebuah masjid yang dalam perjalanan sejarah menjadi pusat aktifitas keagamaan yang berafiliasi kepada mazhab Maliki. Masjidtersebut juga merupakan merupakan lembaga pendidikan yang bonafid selevel dengan Universitas al-Azhar (Halim 2014:19).

Ketika belajar di universitas Zaitunah, Ibnu 'Asyur mengkaji ilmu fiqih,usul fiqih, bahasa Arab, hadis, sejarah, dan lain sebagainya. Ibn 'Asyur mendapatkan gelar sarjananya pada tahun1899M.Kemudian pada tahun 1903 M, iaditugaskanmenjadi guru di almamaeternya (Nikmah 2017:82-83). Pada tahun 1913M, Ibnu 'Asyur diangkat sebagaiseorang Hakim Mazhab Maliki dan juga diangkat sebagai pemimpin muftiMazhab Maliki di Tunisiapada tahun 1927. Ibnu 'Asur juga dikenal sebagai ahli tafsir, bahasa, nahwu dan sastra. Oleh sebab itu, tidak mengeherankan jika ia terpilih menjadi anggota Majma' al-Lugahal-'Arabiyyah di Mesir dan Damaskus pada tahun 1950 (Halim 2014:20). Tidak hanya itu, berbagai jabatan lainya selama hidupnya,antara lainKetua kepala anggota majlis idarah al-Jam’iyah al-Khalduniyyah, Wakil 
pemerintahan bidang penelitian ilmiyah di Universitas Zaituna, ketua Majlis alAuqaf, Ketua qadi Maliki di majlis al-Syari', Rektor universitas Zaituna (Nikmah 2017:84). Sementara itu, berbagai karya monumental yang ditulisnya anatara lain, Maqashid as Syariah al Islamiyah,at Tahrir wa at Tanwir,Ushul Nidham al Ijitima’i fil Islam, Syarhal Muqaddimah al Adabiyah (Toriquddin 2013:196).

Selanjutnya, Muhammad Syahrur (Syahrur). Ia merupakan intelektual muslim yang lahir di Damaskus, Syiria 11April 1938. Setamat pendidikan diploma di Moskow, Syahrur kembali ke Syiria dan mengajar di Fakultas Teknik Sipil Universitas Damaskus. Kemudian tahun 1968, ia mendapat tugas belajar untuk lanjut studi master dan doktornya di Ireland National University dengan mengambil konsentrasi mekanika pertahanan dan teknik bangunan sampai pada akhirnya mendapat gelar master pada tahun 1969, dan doktornya pada 1972. Tidak dipungkiri bahwa pada awalnya, Syarur konsen di Bidang keilmuan Tehnik. Akan tetapi belakangan Syahrur mulai tertarik dan menggeluti studi keislaman, seperti hadis dan al-Qur'an secara serius melalui pendekatan linguistik, filsafat bahkan sains modern.

Titik awal ketertarikan Syahrur terhadap studi ilmukeislaman sejatinya telah dimulainya sejak ia berada di Dublin Irlandia pada tahun 1970-1980, yakni ketika ia sedang menempug program master dan doktornya. Hal ini tidak terlepas dari pengaruh dan peran sahabatnya yang bernama doktor Ja'far Dakk al-Bab. Berkat pertemuannya dengan Ja'far pada tahun 1958 dan 1964, Syahrur mendapat banyak kesempatan belajar tentang studi ilmu bahasa. Pada tahun 1970-1980, Syahrur merasa studi keislaman yang dilakukan selama ini kurang membuahkan hasil, dan tidak ada teori baru yang didapatkannya. Oleh karena itu,ia merasa selama ini terkungkung padapelbagai literaturkeislaman klasik yang cenderung memandang ajaran Islam sebagai idiologi, baik dalam bentuk pemikiran Kalam (Islamic Theology) maupun Fikih. Sebagai implikasinya, maka pemikiran tafsir akan mengalami stagnasi dan nyaris hanya jalan di tempat, sebab selama ini seolah pemikiran tafsir dipandang sebagai produk pemikiran yang final (Mustaqim 2017:4).

Keseriusan Syahrur dalam menggeluti kajian Islam teruatama dalam kajian tentang Hadis dan al-Qur'an dibuktikan dengan berbagai karyanya, antara lain: (1) Qur'an: Qira'ah Mu'ashirah; (2) DirasahIslamiyyah Mu'asirah fi al-Dawlah wa al-Mujtama' (1994), (3) al- Islam wa al-Iman;Manzumat alQiyam (1996), (4) Masyru' Misaq al-'Amal al-Islami. (1999), (5)Nahwa Usul Jadidah li al-Fiqhi al-Islami (2000), (6) al-Sunnah al-Rasuliyyah wa alsunnah al-Nabawiyyah, (2012) (Mustaqim 2017:5). Atas prestasinya dalam pengembangan kajian Islam kontemporer tidak mengerankan jika pada tahun 1995, Syahur pernah terlibat menjadi peserta kehormatan dan dalam debat pemikiran Islam di Lebanon dan Maroko (Andi, Hakim \& Hibatullah 2016:8182).

Berdasarkan uraian diaspora intelektual dan sosial Ibnu 'Asyur dan Muhammad Syahrur sebagaiamana di atas, dapat dikatakan bahwa keduanya merupaka intelektual muslim kontemporer yang memiliki kapasitas ilmu keIslaman yang luas, tidak terkecuali dalam bidang hukum Islam dan tafsir. 


\section{E. STUDI KOMPARATIF CORAK PENAFSIRAN MUHAMMAD TAHIR IBNU 'ASYUR DAN MUHAMMAD SYAHRUR ATAS AL- MA'IDAH AYAT 38}

\section{Tekstualisme Muhammad Tahir Ibnu 'Asyur dalam Penafsiran al-Ma'idah Ayat 38}

Tidak dipungkiri bahwa produk pemikiran hukum Islam (fikih) tidak dapat dilepaskan dariaktifitas penafsiran terhadap landasan teologis normatif Islam, baik al-Qur'an maupun Hadis dalam kondisi danwaktu tertentu (Islamy 2021a:60). Oleh sebab itu, tidaklah mengherankan jika produk pemikiran hukum Islam seringkali beragam meski berpijak pada landasan teks normatif yang sama (Islamy 2017:194). Pada konteks inilah, Amina Wadud juga menuturkan bahwa untuk mendapatkan makna hukum dari suatu teks (ayat), makapenting memperhatikan tiga hal, antara lain konteks, grammatikal teks dan world view yang berkembang (Islamy 2017:28-29).

Terjadinya ragam produk penafsiran meski berpijak pada landasan teks normatif yang sama, seperti halnya terjadi pada penafsiran konsep sanksi hukum potong tangan dalam al-Ma'idah ayat 38. Mazhab Hanafi misalnya (kecuali Abu Yusuf), berpendapat pencopet tidak masuk dalam cakupan kata al-shariq. Sementara mazhab Maliki, Shafi'i, dan Hanbali menyatakan cakupan makna al-shariq dikembalikan pada kultur di masyarakat.(Al-Qurtubi 2003:337). Begitu juga terkait kadar nilai harta atau barang yang dicuri, juga terjadi ragam pendapat di kalangan ulama.Imam Malik Ibn Annas misalnya, menyatakan sanksi hukum potong tangan diterapkan bagi pelaku pencurian harta yang nilainya minimal tiga dirham. Sedangkan al-Qurtubi menyatakan seperempat dinar sebagaimana mengacu pada Hadis Nabi. Paralel dengan pendapat al-Qurtubi, Imam Shafi'i juga memberikan batasan minimal seperempat dinar. Sedangkan Abu Hanifah dan al-Thauri menyatakan minimal sepuluh dirham berdasarkan Hadis Nabi yang diriwayatkan Ibn 'Abbas (Ash-Shabuni 2007:521). Dari sini dapat dikatakan bahwa ragam penafasiran atas sanksi hukum potong dalam alMa'idah ayat 38 memiliki akar geneologis dari penafsiran para ulama klasik.

Sebelum jauh penulis menguraikan penafsiran Muhammad Tahir Ibnu 'Asyur, dalam sub bab ini akan dipaparkan terlebih dahulu redaksi teks ayat al-Maidah ayat 38 beserta arti tekstualnya, sebagai berikut.

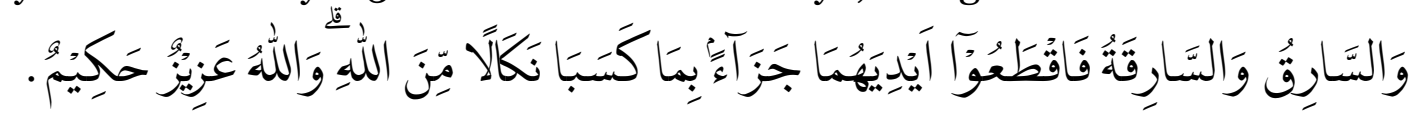

Terjemahannya:

"Laki-laki maupun perempuan yang mencuri, potonglah tangan keduanya sebagai balasan atas perbuatan yang mereka lakukan, dan sebagai siksaan dari Allah. Allah Mahaperkasa lagi Mahabijaksana”. (QS. Al-Maidah [5]: 38).

Dalam merespon ayat di atas, Ibn 'Asyûr menerima dengan sepenuh hati atas pelaksanaan hukum potong tangan bagi pencuri. Menurutnya, hukum potong tangan bernilai mashlahat bagi kehidupan manuisa secara 
luas"(Asyur 1984, 190-92). Lebih lanjut, Ibn 'Asyûr menghubungkan hukum potong tangan dengan hikmah al-tasyrî'. Ia menyatakan bahwa hukum potong tangan merupakan bentuk hukuman bagi pencuri agar mendapat efek jera sehingga tidak akan mengulangi lagi, artinya bukan sebagai bentuk balasan sebagai penyiksaan melainkan sebagai sarana membenahi diri. Adapun mengenai pendapat apakah gugur hukum potong tangan bagi pencuri, Ibn 'Âsyûr berpendapat bahwa hukum potong tangan tidak dapat digugurkan dengan kata taubat, karena mengenai taubat adalah hak Allah di akhirat, dan hal ini juga termasuk membenarkan sikap Rasulullah yang tetap memotong tangan al-Makhzûmiyyah meskipun ia telah taubat. Adapun mengenai perihal pengertian al-sâriq, kadar barang curian dan teknis hukuman tersebut Ibn 'Asyur menyerahkannya kepada ahl al-ijtihâd dari ulama-ulama madzhab sebelumnya (Asyur 1984:193).

Tampaknya Ibn 'Âsyûr yang dikenal sebagai tokoh penafsir modern juga tak dapat melepaskan diri dari teks yang menetapkan hukum potong tangan, ia secara lapang dada menerima ketetapan dari Allah akan pelaksanaan hukum potong tangan bagi pencuri. Jadi dalam pandangan Ibn 'Âsyûr jika pencuri telah ditetapkan sebagai kandidat memperoleh hukuman potong tangan, maka tidak ada pilihan lain. Selain itu, Ibn 'Âsyûr berpendapat hukuman tersebut supaya si pencuri menjadi jera dan sebagai ibrah (pelajaran) bagi orang lain. Tekstualisme penafsiran Ibnu Asyur tersebut tidak dapat dilepaskandalam pendekatan tekstualnya dalam memahami makna harfiah dari redaksi teks ayatal-Maidah 38.Sebagaimana yang dituturkan Abdullah Saaed, bahwa paradigma dalam pendekatan tekstual memiliki dasar keyakinan bahwa makna yang termuat dalam redaksi teks al-Qur'an bersifat universal, yakni dapat diimplementasikan melintasi ruang dan waktu tanpa harus mengacu pada latar belakang sosiohistoris ketika teks al-Qur'an tersebut diturunkan (Kharomen 2018:190).

\section{Kontekstualisme Muhammad Syahrur dalam Penafsiran al-Maidah Ayat 38}

Terjadinya kondisi perubahan sosial dalam kehidupan umat manusia merupakan hukum alam. Tidak dipungkiri bahwa dalam ranah praksisnya, perubahan sosial tersebut akan menuntut adanya pembaharuan dalam segala lini bidang kehidupan, tidak terkecuali pada aspek interpretasi maupun implementasi hukum Islam. Pada konteks inilah, penafsiran hukum Islam dituntut agar dapat senantiasa responsif, adaptif, dan solutif terhadap perkembangan problem hukum di tengah masyarakat (Islamy 2021c:3536).

Anver E.Emon (2006:334) dan Sajila Kausar (2017:151) menyatakan bahwa sebagai norma hukum yang hidup (living law) di masyarakat, keberadaan hukum Islam tidak dapat dilepaskan dari konstruksi sosial budaya umat Islam yang dinamis, kompleks, dan plural. Pernyataan ini paralel dengan apa yang dikatakan oleh tokoh sosiologi hukum Barat, yakni Friedrich Karl Von Savigny. Menurut Savigny, hukum merupakan bagian budaya yang hidup dan berkembang di masyarakat. Oleh sebab itu, keberadaan hukum merupakan bentuk refleksi jiwa suatu kondisi sosial masyarakat tertentu yang dapat berbeda dengan masyarakat lain. Savigny 
menambahkan keberadaan hukum dapat berkembang, melemah dan menguat sesuai dengan kondisi masyarakat yang melitarinya. Senada dengan Von Savigny, Eugen Ehrlich juga mengatakan keberadaan hukum tidak dapat dilepaskan dari kondisi dan kebutuhan masyarakat. Atas dasar inlah, hukum harus dapat adaptif dengan norma yang hidup dan dapat memenuhi kebutuhan masyarakat (Hadi 2017:260-263).

Salah seorang intelektual muslim kontemporer yang mencoba memahami landasan hukum Islam, baik al-Qur'an maupun Hadis dengan pendekatan ilmu kontemporer, yakni Muhammad Syahrur. Ia berhasil menuangkan gagasannya terkait bagaimana cara berinteraksi dengan alQur'an pada era modern. Teori yang diangkat oleh Syahrûr adalah teori batas (hudud) (Syahrur 1990:453-466). Secara eksplisit, ia tidak menjelaskan apa yang dimaksud dengan teori batas. Namun maksudnya, yakni perintah tuhan yang diungkapkan dalam al-Qur'an dan Sunnah yang berisi ketentuan-ketentuan batas terendah (al- $\underline{H}$ add al-Adna) dan batas

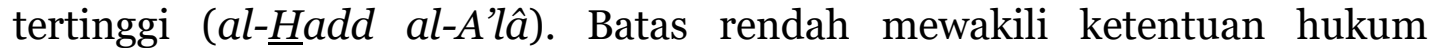
minimun dalam sebuah kasus hukum, dan batas tertinggi mewakili batas maksimumnya (Fateh 2017:16-17).

Ketika Syahrûr memahami ayat tentang hukuman potong tangan sebagaimana dalam al-Maidah ayat 38, ia memasukkannya ke dalam teori al-hadd al-a'la. Dari sisi kebahasaan, ia mengatakan bahwa kata al-nakâl dalam bahasa arab berasal dari kata nakl yang berarti al-man'u yang kemudian dipahami dengan suatu perbuatan yang dapat mencegah dari mengulanginya. Lebih lanjut ia hukuman yang tertinggi bagi pencuri adalah potong tangan sehingga tidak diperbolehkan menjatuhkan hukuman melebihi potong tangan. Atas dasar inilah, diberi kebebasan kepada suatu negara menetapkan hukuman yang sesuai dengan masanya, namun dengan catatan tidak boleh melampaui dari potong tangan (Syahrur 1990:455).

Penafsiran Syahrûr pada kasus hukum potong tangan bagi pencuri dapat dikateogrikan pada penafsiran kontekstualis. Hal ini dapat dilihat ketika ia memahami ayat potong tangan bagi pencuri, ia memberikan pemaknaan yang memberi ruang ijtihad bagi suatu daerah atau tempat untuk menegakkan hukuman yang memberi efek jera, dengan ketentuan tidak boleh melampaui hukuman potong tangan.Menurut penulis, penafsiran Syahrûr ini dapat diterapkan untuk segala ruang dan waktu, dan menunjukkan bahwa kesepakatan kolektif dapat dijadikan dasar hukum suatu daerah atau negara. Syahrûr dalam pemikirannya telah membuktikan bahwa ada suatu cara yang lebih sesuai dengan era modern.Kontekstualisme penafsiran Syahrur tersebut paralel dengan nilai-nilai implementasi (implementation values) dalam teori hirarki penafsiran sebagaimana yang dicetuskan Abdullah Saeed. MenurutSaeed, pelbagai nilai pada level nilai implementasi merupakan langkah konkrit yang bersifat teknis dalam menjaga nilai-nilai fundamental. Ia mencontohkan pencegahan pencurian dalam al-Qur'an diaktualisasikan melalui sanksi hukum potong tangan. Sanksi hukum yang berupa potong tangan tersebut merupakan bentuk legal instrumen sebagai langkah prefentif agar tidak terjadi pelanggaran yang serupa. Menurut Saeed, sebagai bentuk legal instrument, sanksi hukum bagi orang yang mengambil hak milik orang lain tidak hanya dalam bentuk 
potong tangan, tetapi dapat dikontekstualisasikan dalam beragam bentuk yang efektif sesuai dengan kondisi yang ada (Saeed 2005:134-136).

\section{Penafsiran Integratif: Implikasi Teoritik Atas Corak Tekstualisme Muhamad Tahir Ibn 'Asyur dan Kontekstualisme Muhammad Syahrur al-Maidah Ayat 38}

Salah satu pertayaan fundamental bagi umat Islam terkait pemahaman terhadap teks normative ajaran Islam keagamaan, yakni bagaimana umat Islam dapat hidup sesuai dengan tuntutan teks agama tersebut sekaligus dapat beradaptasi dengan peradaban kehidupan yang berkembang beserta problem yang mengirinya? Dengan kata lain, bagaimana di satu pihak umat Islam dapat terus menyesuaikan diri dengan perubahan, tetapi di pihak lain tetap menjadi umat Islam yang baik? Namun tidak dipungkiri persoalan tersebut menjadi problem hermeneutis dalam diskursus pemikiran ke-Islaman tentang bagaimana merumuskan relasi dialektis antara universalitas dengan partikularitas, dan juga antara normativitas dengan historisitas ajaran Islam. Dua pertanyaan hermeneutis tersebut memunculkan dua pendekatan dalam studi pemikiran Islam berupa pendektan normatif dan historis (Nasitotul Jannah 2018:102).

Jika dikaitkan dengan distinsi corak penafsiran tektualis Ibnu Asyur dan penafsiran kontekstual Syahrur, maka dapat dikatakan bahwas argumen yang tetap dipegangi oleh Ibnu Asyur, yakni teks (nas) diturunkan dan ditetapkan bukan tanpa tujuan. Oleh karenanya tidak rasional, jika ada hukum yang secara teks telah ada, akan tetapi masih mencoba mencari alternatif penafsiran yang pada aplikasinya dapat memicu produk penafsiran yang dapat sangat berbeda dengan makna yang termaktub dalam redaksi teks nas al-Ma'idah ayat 38. Sedangkan argumen yang oleh Muhammad Syahrur tidak menekankan pada makna termaktub dalam redaksi teks (nas) al-Ma'idah ayat 38, melainkan lebih mencoba mencari alternatif penafsiran yang pada aplikasinya dapat menyesuaikan dengan kondisi kasus yang dihadapi.

Sebagai implikasi teoritik penulis mencoba untuk mengkombinasikan penafsiran tekstualis Ibnu 'Asyur dan kontekstualis Muhammad Syahrur. Jika dari sisi penafsiran tekstualis, penulis mengajukan perluasan pemaknaan kata sâriq, yang implikasinya tentu yang dimaksud pencuri bukan hanya seseorang yang mengambil hak milik orang lain secara sembunyi-sembunyi, maka masuk di dalamnya perampokan, penjambretan, korupsi, dan lain sebagainya. Kemudian dipadukan dengan penafsiran kontekstual Syahrur melalui pendekatan teori batas yang ditawarkannya. Artinya bahwa suatu masyarakat dikenakan sanksi jika melakukan tindak pencurian baik yang bersifat materi maupun yang immateri, namun hukuman tersebut sesuai dengan kebiasaan masyarakat tersebut hanya saja tidak boleh melebihi batas maksimal, yakni potong tangan. Sehingga dengan ini, tujuan dari kedua kelompok tersebut dapat terealisasi, yakni masyarakat yang damai dengan didasari hukum yang tidak lebih dari potong tangan. 


\section{F. KESIMPULAN}

Berpijak pada pembahasan inti penelitian ini dapat disimpulkan bahwa tekstualisme penafsiran Muhammad Tahir Ibnu 'Asyur terkait al-Ma'idah ayat 38 dapat dilihat dari penafsirannya atas makna harfiyah dari ayat tersebut. Menurutnya, sanksi hukuman pencuri telah ditetapkan dalam ayat tersebutdalam bentuk hukuman potong tangan. Selain itu, Ibnu 'Asyur juga memandang hukuman potong tanganbagi pencuri sebagai bentuk hukuman jera sekaligus upaya prefentif ('ibrah) agar tidak terjadi pencurian serupa. Berbeda dengan Ibnu 'Asyur, penafsiran Muhammad Syahrur pada kasus hukum potong tangan bagi pencuri termasuk penafsiran kontekstualis.Hal ini dapat dilihat ketika ia memahami ayat potong tangan bagi pencuri dengan penafsiran yang memberikan ruang ijtihad bagi suatu daerah atau kondisi tertentu untuk menegakkan hukuman yang memberi efek jera, dengan ketentuan tidak boleh melampaui hukuman potong tangan sebagai batas maksimal.Implikasi penafsiran Syahrur tersebut dapat diterapkan untuk segala ruang dan waktu, dan menunjukkan bahwa kesepakatan kolektif dapat dijadikan dasar hukum suatu daerah atau negara.

Penelitian ini masih sebatas pada tahap istinbat al-hukm (penggalian hukum) dari nas yang fokus pada aspek corak penafsiran hukum atas al-Maidah ayat 38 dari kedua tokoh pemikir hukum Islam kontemporer yakmi, Ibn Asyur dan Muhammad Syahrur. Oleh sebab itu, dibutuhkan lebih lnjut penelitian yang fokus pada tahab tatbiq al-hukm (aplikasi/penerapan hukum) yang berpijak pada produk penafsiran atas al-Maidah ayat 38 dari kedua tokoh tersebut

\section{REFERENSI}

\section{Buku (Kitab)}

Al-Qurtubi, Ibn Rushd. (2003). Bidayat al-mujtahid wa nihayat al-muqtasid. Dar al-Kotob al-IImiyah.

Ash-Shabuni, Muhammad 'Ali. (2007). Rawai'u al-Bayan Tafsir Ayatu alAhkam. al-Qahirah: Dar ash-Shabuni.

Asyur, Muhammad Al-Thahrir ibn. (1984). al-Tahrîr wa al-Tanwîr. Tunisia: alDar al-Tunisiyah.

Dimasyqî, Ismâ’il bin 'Umar Ibn Katsîr al-. (1998). Tafsîr al-Qur'ân al-'Azîm. Beirut: Dâr al-Kutub al-'Ilmiyyah.

Karim, Khalil Abdul. (2003). Syariah: Sejarah Perkelahian Pemaknaan. Yogyakarta: LkiS.

Moleong, Lexy J. (2017). Metodologi Penelitian Kualitatif. Bandung: Remaja Rosdakarya.

R.I, Kementrian Agama. (2010). Mushaf Al-Azhar Al-Qur'an Dan Terjemahan. Bandung: Hilal.

Saeed, Abdullah. (2005). Interpreting the Qur'an: towards a contemporary approach. Routledge.

Syahrur, Muhammad. (1990). al-Kitâb wa al-Qur'ân Qirâ'ah Mu'asirah. Damaskus: al-Ahalli li al-Tibâ'ah. 
Syatawî, Ibrâhîm bin 'Abd al-'Azîz al-. (1998). Bahts Muhkam:'Uqûbah al-Sâriq fi al-Marrâth al-Khams Dirâsah Hadîtsiyyah Maudû'iyyah. Riyadh.

Tabarî, Abu Ja'far Muhammad bin Jarîr al-. (2001). Tafsîr al-Tabarî Jâmi’ alBayân 'An Ta'wîli Ay al-Qur'ân. Kairo: T.pn.

\section{Jurnal, Disertasi, dan Tesis}

Andi, Azhari, Luqman Hakim, dan Mutawakkil Hibatullah. (2016). Reinterpretasi Sunnah: (Studi Pemikiran Muhammad Syahrur terhadap Sunnah). Jurnal Living Hadis, 1(1): 79-100.

Arni, Jani. (2011). Tafsir al-Tahrir Wa al Tanwir Karya Muhammad Al-Thahrir ibn Asyur. Jurnal Ushuluddin, 17(1): 80-97.

Emon, Anver M. (2006). Conceiving Islamic law in a pluralist society: History, politics and multicultural jurisprudence. Singapore Journal of Legal Studies, Dec 2006: 331.

Fateh, Mohammad. (2010). Hermeneutika Sahrur: (Metode Alternatif Interpretasi Teks-Teks Keagamaan). RELIGIA: Jurnal Ilmu-Ilmu Keislaman, 13(1), 1-21.

Hadi, Syofyan. (2017). Hukum Positif dan The Living Law (Eksistensi dan Keberlakuannya dalam Masyarakat)" DiH: Jurnal Ilmu Hukum.

Halim, Abd. (2014). Kitab Tafsir al-Tahrir wa al-Tanwir Karya Ibnu 'Asyur dan Kontribusinya Terhadap Keilmuan Tafsir Kontemporer. Jurnal Syahadah, 2(2), 16-30.

Islamy, Athoillah. (2017). Gender Mainstreaming dalam al-Qur'an dan Hadis serta Relevansinya Terhadap Epistemologi Hukum Islam. Jurnal Hukum Islam, 15(1), 181-199.

- - - (2021a). Landasan Filosofis dan Corak Pendekatan Abdurrahman Wahid Tentang Implementasi Hukum Islam di Indonesia. Al-Adalah: Jurnal Hukum dan Politik Islam, 6(1): 51-73.

- - . (2021b). Nilai-Nilai Maqasid Syariah dalam Fungsi Keluarga di Tengah Pandemi Covid-19. Al-Qisthu: Jurnal Kajian Ilmu-Ilmu Hukum, 19(01), $1-12$.

---. (2021c). Pemikiran Hukum Islam Nurcholish Madjid. Semarang: Disertasi Pascasarjana Universitas Islam Negeri Walisongo.

Janah, Nasitotul. (2018). Pendekatan Normativitas Dan Historisitas Serta Implikasinya Dalam Perkembangan Pemikiran Islam, Cakrawala: Jurnal Studi Islam, 13(2), 102.

Kausar, Sajila. (2017). Collective Ijtihad: History and Current Perspective. International Journal of Humanities \& Social Science Studies, 3(5).

Kharomen, Agus Imam. (2018). Bias Awal Penciptaan Perempuan Dalam Tafsir Alquran (Perspektif Pendekatan Tekstual dan Kontekstual). AL-QUDS: Jurnal Studi Alquran dan Hadis, 2(2), 187-204.

Mamluchah, Laila. (2020). Peningkatan Angka Kejahatan Pencurian Pada Masa Pandemi Dalam Tinjauan Kriminologi dan Hukum Pidana Islam. AlJinayah: Jurnal Hukum Pidana Islam, 6(1), 1-26.

Mansyuroh, Firqah Annajiyah. (2019). Hukum Potong Tangan Bagi Koruptor (Kajian Ahkam Surah Al-Maidah Ayat 38). Dialogia: Jurnal Studi Islam Dan Sosial, 17(1), 41-60. 
Mardani, Mardani. (2008). Sanksi Potong Tangan Bagi Pelaku Tindak Pidana Pencurian dalam Perspektif Hukum Islam. Jurnal Hukum IUS QUIA IUSTUM, 15(2).

Mustaqim, Abdul. (2017). Teori Hudûd Muhammad Syahrur dan kontribusinya dalam penafsiran al-Qur'an. AL-QUDS: Jurnal Studi Alquran dan Hadis, 1(1), 01-26.

Nikmah, Lutfiyatun. (2017). Penafsiran Țāhir Ibn 'Āsyūr Terhadap Ayat-ayat tentang Demokrasi: Kajian atas Tafsir al-Tahrīr wa al-Tanwīr. Journal of Islamic Studies and Humanities, 2(1), 79-103.

Rahmi, Nailul. (2018). Hukuman Potong Tangan Perspektif Al-Quran Dan Hadis. Jurnal Ulunnuha, 7(2), 53-70.

Ridwan, Nursyamsudin. (2016). Metodologi Hukum Muhammad Shahrur: Tafsir Hadd Pencurian Dalam Qs. Al-Māidah (5): 38. Mahkamah: Jurnal Kajian Hukum Islam, 1(2).

Sama'un, Sama'un. (2019). Epistemologi Tafsir Kontekstual: Analisis Teori Hirarki Values terhadap ayat-ayat Al Quran. Thesis, UIN Sunan Ampel Surabaya.

Tazkiyah, Izzatu. (2018). Paradigma Tekstual Atau Kontekstual Dalam Penafsiran Quraish Shihab. Jurnal Ilmiah Pesantren, 2(2).

Toriquddin, Moh. (2013). Teori Maqashid Syari'ah Perspektif Ibnu Ashur. Ulul Albab: Jurnal Studi Islam, 14(2), 184-212.

Triana, Anggita Ayu, \& Agus Machfud Fauzi. (2020). Dampak Pandemi Corona Virus Diserse 19 Terhadap Meningkatnya Kriminalitas Pencurian Sepeda Motor Di Surabaya. Syiah Kuala Law Journal, 4(3), 302-309.

Ulummudin, Ulummudin. (2019). Analisis Penafsiran Terhadap Surat AlMa'idah: 38 Dalam Al-Qur'an (A Reformist Translation). QOF: Jurnal Studi Al-Qur'an dan Tafsir, 3(2), 147-159.

Yunus, Nur Rohim, \& Annissa Rezki. (2020). Kebijakan Pemberlakuan Lock Down Sebagai Antisipasi Penyebaran Corona Virus Covid-19. Salam: Jurnal Sosial dan Budaya Syar-i, 7(3), 227-238. 